\title{
„Pénzügy és gazdasági fejlődés hosszú távon” \\ Shin, Yongseok (2018): Finance and Economic Development on the Very Long Run: A Review Essay (Journal of Economic Literature, 56(4), 1557-1586.) ${ }^{1}$
}

Yongseok Shin esszéjében Goetzmann Money Changes Everything: How Finance Made Civilizations Possible címü könyvéröl ír bemutatót, majd a könyv hipotézisét továbbgondolva vizsgálja, vajon az egyes pénzügyi találmányok hatást gyakorolnak-e a hosszú távú gazdasági fejlődésre. Shin Goetzmann müvét további gazdaságtörténelmi elemzésekkel is összeveti. Arra a következtetésre jut, hogy a pénzügyek jelenléte fontos összetevő egy jól müködő gazdaságban, azonban nem lehet az egyetlen fejlődést előidéző tényező. Shin a pénzügyi történelem további alapos tanulmányozását javasolja, és azt a jelenlegi pénzügyi szektor szabályozásainak kialakítása során is hasznosnak véli.

Yongseok Shin reviews Goetzmann's book, titled Money Changes Everything: How Finance Made Civilizations Possible. He reinterprets its main hypothesis, and analyses how the presence of financial tools affect economic development in the very long run. He also compares Goetzmann's viewpoint to other economic historians' results. He concludes that financial advancement is certainly one of the key factors leading to a prosperous economy, but cannot be the single one. Shin argues that financial history lessons might enable us to create more adequate financial regulations.

\section{Bevezetés}

William N. Goetzmann 2016-ban megjelent Money Changes Everything: How Finance Made Civilizations Possible címü müve egy történelmi korokon és tudományterületeken átívelő munka. Több mint 5000 év történelmét áttekintve vizsgálja, hogy a pénzügy hogyan hat a civilizációk kialakulására, illetve azok fennmaradására és fejlődésére. Erről a könyvről ír esszét Yongseok Shin, aki elismeri a könyv mögötti óriási interdiszciplináris eredményt, és hatalmas jelentőségü munkának titulálja azt. Goetztmann mủvét irányadónak tartja, egy olyan nagy átfogó történelmi áttekintésnek, amely ráébreszthet minket arra, hogy fejlett pénzügyi rendszereink és a sosem látott gazdasági jólét ellenére (vagy talán éppen azért) érdemes tanulnunk a történelmünkböl. Shin a könyv gondolatmenetét tovább viszi, és a könyvben bemutatott pénzügyi történelem alapján három kérdésre keresi a választ: 1) Gazdasági fejlődést okoz-e a pénzügyek jelenléte és fejlődése? 2) Miért előzte le gazdasági fejlettségben Európa Kínát az 1800-as évektől, és játszhatott-e ebben szerepet az eltérö pénzügyi gondolkodás? 3) Hogyan hatottak az egyes pénzügyi megoldások az egyének életére a történelemben?

\section{A pénzügyek történelme}

Goetzmann könyve az ókori Mezopotámiában kezdődik, az ókori sumer városokban. Goetzmann leírja, hogy a városok elhelyezkedése a gabonatermesztés és állattartás szempontjából ideálisnak volt tekinthető,

\footnotetext{
${ }^{1}$ Shin, Yongseok (2018): Finance and Economic Development on the Very Long Run: A Review Essay, Journal of Economic Literature, 56(4), 1557-1586 https://doi.org/10.1257/jel.20171407

DOI: $10.14267 /$ RETP2021.01.16
} 
azonban a terület hiányt szenvedett olyan nyersanyagokban, amelyek a Kr.e. 4. évezredben a bronz készítéséhez szükségesek voltak. A mezopotámiaiak hosszú távú kereskedelmi ügyleteket bonyolítottak le ezekért az árukért. Emellett az ókori mezopotámiai kultúrák gazdasága a helyi termelés újraelosztását is igényelte. A távoli kereskedelem és az újraelosztás nyilvántartására alakult ki a pénzügyi rendszer ezekben a városállamokban. Nem véletlen, hogy itt alakult ki először az írás: Goetzmann úgy tartja, hogy a sumer ékírás a gazdasági tranzakciók könyvelésének köszönhetően alakult ki - Uruk legrégebbi agyagtáblái nagyjából Kr.e. 3100-ból származnak, és ezek rendre a könyvelésekhez kapcsolódnak. A gazdasági tranzakciók feljegyzéséhez természetesen egy kidolgozott és absztrakt számrendszerre is szükség volt, így a matematika tudománya is ennek köszönhetően indult útnak. Meglepő és kissé profán a tény, hogy az írás és a matematika nem a tudomány, a müvészet, vagy a vallás, hanem a kereskedelem nevében jött létre.

Ezen túlmenően Goetzmann szerint az idő absztrakt fogalma és annak gyakorlati és formalizált mérése is a pénzügyeknek köszönhető. A kereskedelmi ügyletek könyveléséhez, a kölcsönök kamatainak kiszámításához egy matematikailag könnyen kezelhető időfogalomra volt szükség. A sumérok bevezették tehát a 360 napos évet, ami matematikailag a legkönnyebben kezelhető. (Valószínüleg a mai könyvelők sem bánnák, ha 360 napból állna egy év).

Az idő és a pénzügyek összefüggése központi szerepet kap Goetzmann művében. „Financial technology is a time machine" (azaz a pénzügyi technológia egy időgép), ötletek és gyakorlatok összessége, amelyek képessé tesznek minket arra, hogy a gazdasági értéket időben előre és hátra mozgassuk. Megtakarítás és befektetés által jelenbeli fogyasztásunkat jövőbelire cserélhetjük, hitelfelvétellel jelenbeli fogyasztást vásárolhatunk, melyért a jövőben fogunk megfizetni. Goetzmann pénzügy mögötti implicit definíciója mutat rá Shin - lefed minden olyan gazdasági tranzakciót, amely intertemporális döntéseket tartalmaz, ily módon a gazdasági tevékenységek eléggé széles körére érvényes. Ennek ismeretében talán kissé kevésbé tünik bátornak és provokatívnak a címben megfogalmazott állítás, miszerint a pénzügyek tették lehetővé a civilizáció kialakulását.

Mezopotámia után Athént és Rómát mutatja be a könyv, ahol a kereskedelem és a jog fejlettsége megdöbbentheti az olvasót, ráadásul mind az athéni, mind a római nép igen kimagasló pénzügyi és jogi tájékozottsággal rendelkezett. Ezt követően a könyv Kínába látogat el, ahol a Kr.e. 4. századtól kezdve igen haladó tudományos elméletek születtek a gazdaság egyensúlyteremtő hatásairól. A papírpénz is kínai találmány, mellyel Európából Marco Polo találkozhatott először. Shin érvelése szerint a Kínát bemutató fejezet fö tanulsága, hogy a pénzügyi rendszer kiépítése egymástól teljesen eltérő és elzárt kultúrák esetén tartalmaz hasonlóságokat, de különbségeket is: ugyanazon gondolkodás a helyi viszonyokhoz alakulva ölt testet. Goetzmann is felveti a lehetőségét annak, hogy a kínai és európai pénzügyi rendszer különbségei eredményezhették Európa feltörekvését és Kína lemaradását a 18. századtól.

A könyv ezután Európa és a nyugati világ gazdasági fejlődését veszi górcső alá. Megtudhatjuk, hogy a késő középkorban Velencében és Genovában az állam szokásos forrásszerző tevékenységei közé tartozott az államkötvények kibocsátása, amelyeknek meglehetősen likvid másodpiaca is müködött. A pénzügyek a földrajzi felfedezések korában váltak még fontosabbá, ekkortól már megkérdőjelezhetetlen a központi szerepük az európai civilizáció felemelkedésében. A felfedezőutak hosszú lejáratú és kockázatos befektetések voltak, azonban igen magas hozammal kecsegtettek. Relevánssá vált tehát a megtakarítók forrástöbbleteinek hatékony eljuttatása a forrásigénylőkhöz. A felfedezőutak forrásszerzése mind idegen tőke (hitel), mind saját tőke (részvénytársaságok) formájában jelen volt. A Holland és a Brit Kelet-indiai Társaság a mai részvénytársaságokhoz hasonlóan szerzett forrást felfedező útjaihoz, melyek eredményeként leigázták a Távol-Kelet jelentős részét. A saját tőke finanszírozás a tőzsdék fejlődését vonzotta maga után. Ennek a folyamatnak a mellékhatásaként a pénzpiaci buborékok sem voltak ritkák, az 
egyik legnagyobb jelentőségü példa erre a Mississippi Buborék volt Franciaországban 1720-ban, de Hollandia és Anglia pénzpiacai sem voltak ezen jelenségektől mentesek. Angliában a Déltengeri Buborék (amely ugyanazon évben történt, amikor Franciaországban a Mississippi Buborék) kidurranása után lépett életbe a Bubble Act, amely jelentősen szabályozta a korlátolt felelősségű társaságok alapítását. Ezt követően az ipari forradalom találmányainak és új üzleti megoldásainak finanszírozása nem saját tőkéböl, hanem inkább banki hitelekböl valósult meg, és a pénzpiacokon is a kötvények (vállalati és államkötvények) váltak a legtöbbet kereskedett értékpapírokká.

Az újkori Európában ezen kívül a matematika is jelentős fejlődésnek indult. A valószínüségszámítás sokat tett hozzá az egyes értékpapírok, részvények, kötvények, derivatívák árazásához.

Shin szerint két fő konklúzió vonható le. Az első, hogy már az ókori társadalmak is kifinomult pénzügyekkel rendelkeztek, az ókori pénzrendszerek bizonyos elemei napjaink gazdaságaiban is fellelhetők, vagy azokból eredeztethetők. A pénzügyek pozitív hatásai (forrásszerzés a kockázatos beruházásokhoz) és a negatív hatásai (buborékok, hitelválságok) egyaránt folyamatos velejárói voltak a társadalmi és gazdasági fejlődésnek. A második pedig, hogy a pénzügyi rendszer egy adott kultúrában mindig illeszkedik a gazdaság szerkezetéhez, kulturális sajátosságokhoz. Shin ezekből kiindulva valamivel provokatívabb kérdéseket tesz fel, amelyek nem inkonzisztensek a könyv hipotézisével, azonban Goetzmann nem ad rájuk egyértelmü választ.

\section{Gazdasági fejlődéshez vezet-e a pénzügy?}

Shin szerint a legnagyobb kérdés a közgazdaság-tudományban, hogy miért vannak gazdag országok, és miért vannak szegények. Mivel a gazdasági fejlettség és a pénzügyek jelenléte között van egy pozitív korreláció, így adódik a kérdés, hogy vajon a pénzügyek megmagyarázhatják-e országok gazdagságát és szegénységét. Shin oly módon interpretálja a kérdést, hogy vajon a pénzügy szükséges vagy elégséges feltétele a gazdasági fejlődésnek?

Az első és legerőteljesebb kérdés, hogy elégséges feltétele-e. Shin szerint Goetzmann könyve ezen a ponton egyértelmü: mivel az ókori civilizációk meglehetősen kifinomult pénzügyeik ellenére sem értek a 19. század Nyugat-Európája életszínvonalának közelébe, így a pénzügyek jelenléte önmagában nem lehet elegendő a gazdaság prosperálásához. Az egy fokkal enyhébb feltevés, miszerint a pénzügy szükséges feltétele a gazdasági fejlődésnek, a könyv alapján igaznak tűnik, különösen a pénzügyek olyan tágan vett értelmezésében, amelyet Goetzmann is alkalmaz. Shin azonban felhívja a figyelmet, hogy a Római Császárság és Kína példája ennek ellentmondhat, és az erős, központosító államhatalom akár alternatívája is lehet a pénzügyeknek. Ez a feltevés azonban, ahogyan Shin a gondolatmenetét továbbviszi, nem illeszkedik az Adam Smith óta kialakult közgazdaság-tudományi consensus sapientiumhoz, miszerint a specializáció és a munkamegosztás a gazdasági fejlődés kulcsfontosságú eleme, az csak a fentebb definiált pénzügy mellett valósulhat meg hatékonyan.

Shin érvelése szerint a szükséges-elégséges dilemma bár érdekes kiindulópont, valójában nem ez a fontos kérdés, hiszen az egyes gazdaságok nem abban különböznek, hogy az egyik egyáltalán semmilyen pénzügyi rendszerrel nem rendelkezik, míg a másik igen, hanem a pénzügyek kiterjedtségében és mélységében. Ezen felül nyilvánvalóan a pénzügyek jelenléte nem lehet az egyetlen tényező, amely egy adott országot elindít a gazdasági fejlődés útján, így a kérdés inkább az, hogy mennyire fontos a pénzügyek szerepe a többi tényezőhöz képest.

Shin ezt követően a pénzügyek gazdasági növekedésre gyakorolt hatását kvantifikálni próbáló empirikus elemzéseket mutatja be. Állítása szerint kezdetben ezek a schumpeteri hipotézisből indultak ki, amely 
szerint az innovációhoz és a vállalkozásokhoz jól müködő pénzpiacok szükségesek. Ezen a téren King és Levin [1990], valamint Rajan és Zingales [1998] munkáját idézi. Shin leírja, hogy bár ezen kutatások empirikus adatok alapján kapcsolatot véltek feltárni a pénzügyi rendszer mértéke és a gazdasági növekedés között, valójában csak az együttjárásra jelentenek bizonyítékot, az okozatiságra nem.

Buera, Kaboski és Shin [2011] egy strukturálisabb, modell-alapú megközelítéssel igyekeznek választ találni ugyanarra a kérdésre. Azt találták, hogy amennyiben egy országban a semmi pénzügyhöz képest egy tökéletes pénzügyi rendszer épül ki, akkor ezzel a lépéssel megduplázódik az egy dolgozóra jutó jövedelem. A konkrét hatást ugyan kimutatta az elemzésük, azonban ez a fajta különbség csak töredéke az országok közötti jövedelemkülönbségeknek, így ez alapján a pénzügyi rendszer szerepe kisebb a vártnál.

\section{A Needham-kérdés}

Shin a gondolatmenetét továbbfüzve arra hívja fel a figyelmet, hogy a végső kérdés mégsem az, hogy a pénzügyek jelenléte gazdasági fejlődéshez vezet-e, hiszen amennyiben erre egyértelmü igen választ is kapnánk, a kérdés továbbgyürüzne, hogy ezesetben miért alakul ki bizonyos országokban fejlett pénzügyi rendszer, míg másokban nem. Shin ezt a kérdést viszi tovább az esszéjében, melyet a Needham-kérdés kontextusában vizsgál. A Needham-kérdés röviden: miért előzte meg a nyugati világ gazdasági fejlődésben Kínát. Kicsit jobban kifejtve arról van szó, hogy a modern tudomány, a természet matematika általi leírása és megértése miért csak a nyugati világban lobbantotta be a technológia lángját az újkorban? Kína az újkort megelőzően sokkal hatékonyabb volt a természeti tudás gyakorlati alkalmazásában, mint a nyugat, azt követően viszont elvesztette ezen előnyét, az 1800-as évektől kezdve pedig teljesen lemaradt a gazdasági és technológiai versenyben. Az iránytü, a puskapor kínai találmány, azonban ezekkel mégsem Kína, hanem Nyugat-Európa terjesztette ki az uralmát a világ felett.

Shin esszéje Goetzmann könyvére támaszkodva azt tárja fel, hogy a pénzügyi technológiát tekintve milyen lényegi különbségek adódtak Kína és Nyugat-Európa között, amelyek az eltérő fejlődési pályához vezethettek. Eszerint a legfőbb különbség az európai államok kötvényeken keresztüli adósságfelhalmozása volt, amelyet egy likvid másodlagos kötvénypiac biztosított. Azonban Shin rámutat arra, hogy az időzítés akkor sem megfelelö, hiszen az államkötvényeken keresztüli forrásbevonás már a 13. századtól jellemző volt bizonyos itáliai városállamokban, míg a gazdaságtörténészek részéről abban egyetértés mutatkozik, hogy az 1800-as évekig nem volt lényeges életszínvonalbeli különbség Európa és Kína között. Ezen túl az állami adósságfelhalmozás gazdasági növekedést előidéző hatása sem egyértelműen meghatározott.

Shin azonban úgy érvel, hogy nem is ez a végső kérdés, hiszen ha egyértelmüen kimutatható is lenne az állami adósságfelhalmozás és a másodlagos kötvénypiacok növekedésösztönző hatása, akkor is továbbgyürüzne a kérdés, hogy mégis miért alapoztak a kötvényeken keresztüli finanszírozásra a nyugateurópai államok, a kínaiak azonban nem? Erre egy lehetséges válaszként nevesíti Shin a földrajzi adottságokat: Európában az egyes államok folyamatos versenyben, sőt harcban álltak egymással, és az államkötvények is gyakran a háborús kiadások fedezetéül szolgáltak. Ezzel szemben Kína a történelem túlnyomó részében egy stabil állam maradt, nem volt szüksége olyan mértékü háborús kiadásokra, mint az európai hatalmaknak.

Goetzmann könyvében Kína lemaradásának és Európa elöretörésének egy újabb lehetséges magyarázatát is bemutatja: a 17. századtól Európában a matematikán belül a valószínüségszámítás gyors fejlődésnek indult, ez a tudományos fejlődés Kínában nem mutatkozott. A valószínüségszámítás a kockázatok kezelésében, ezáltal az egyes eszközök, befektetések árazásában, a kockázatok megértésében fontos szerepet játszhatott, ami egy lehetséges összetevője lehetett az eltérő fejlődési pályának. Shin 
azonban - amellett, hogy elismeri az érvelés ésszerü voltát - két ponton vitába száll ezen hipotézissel: egyrészről az emberiség a történelem korábbi szakaszaiban igazán fejlett valószínűségszámítási ismeretek nélkül is sikeresen tudott kockázatos projekteket megfelelően finanszírozni, másrészt a napjainkban is rendszeres időközönként fellobbanó pénzügyi válságok (a 2007-08-as válságot is ideértve) szintén az ellen szólnak, hogy a fejlett valószínűségszámítási ismeretek létfontosságúak lennének a kockázatok megfelelő kezelésében, de a nyugdíjrendszerek alulfinanszírozottságát is a kockázatok egyfajta félreárazásának tartja. A fentiek mellett Shin a Great Divergence magyarázatára Mokyr [2002, 2016] munkásságát mutatja még be. Mokyr a hosszú távú gazdasági növekedés modern elméletéhez igazodva a tudás és a technológia szerepére összpontosít. Az ő olvasata szerint a fö különbség Európa és Kína között az 1800-as évektől kezdve az volt, hogy Európa fel tudta gyorsítani a technológiai innovációt, ezzel szemben Kínában ez a folyamat elmaradt. Ennek magyarázatát szerinte a felvilágosodás eltérő jellegében és ebből származó eltérő hatásában kell keresni. Európában a felvilágosult gondolkodók szellemisége leszürődött a gyakorlati területre is: az ipari forradalom során a legtöbb találmányt müszaki emberek, mérnökök, technikusok fejlesztették ki gyakorlat közben, nem a felvilágosult gondolkodók. Kínában ezzel szemben a felvilágosult értelmiség nem igazán folytatott diskurzust a gyakorlati emberekkel, így a folyamatos technikai vívmányok itt el is maradtak. Ezek mellett Mokyr az intézmények eltérő fejlődését is hangsúlyozza, amely Európában sikeresen tudta csökkenteni a járadékvadász magatartást.

Összességében Shin nem tartja meggyőzőnek, hogy a pénzügyek eltérő fejlődése a Great Divergence fő okozója. A pénzügyi rendszer fejlődésének eltérését a földrajzi, politikai és kulturális különbségek mellékhatásának tartja.

\section{Pénzügyek hatása az egyénre}

Shin új megközelítésben igyekszik megítélni a pénzügyek gazdasági növekedéshez és jóléthez füződő viszonyát. Azt állítja, hogy a történelmi áttekintés során nem szükséges minden esetben annak a vizsgálatára szorítkoznunk, hogy egy adott pénzügyi találmány, pénzügyi megoldás valóban hozzájárult-e a hosszú távú fejlődéshez, hanem elegendő lehet az is, ha csak azt a kérdést tesszük fel, hogy rövid távon javította-e az érintettek jóléti helyzetét. Goetzmann könyvének ilyen történeteiből kiindulva mutatja be, hogy sokszor bár kérdéses, hogy egy adott pénzügyi megoldás hatékony volt-e a gazdasági növekedés hosszú távú előremozdítása szempontjából, az egyének életét pozitívan alakította. A legjobb példa erre a velencei államkötvények esete, amely ugyan nem tisztázott, hogy mennyiben segítette elő a közpénzügyek hatékony menedzselését, az azonban bizonyos, hogy a kisbefektetők számára megtakarítási szempontból nagyon jó eszköznek bizonyult, és például a dolgozók nyugdíjcélú megtakarításként is előszeretettel gondoltak ezen államkötvényekre. Az ilyen megtakarítások, illetve a kölcsönök által a fogyasztás időben utaztathatóvá vált, ahogyan Goetzmann is fogalmaz, és ami könyvének is talán egyik legfontosabb üzenete: „Finance is a time machine”.

Ugyanakkor Shin óva int attól, hogy megfeledkezzünk a pénzügyek „sötét oldaláról”. Az illegális tevékenységeken, csalásokon (Charles Ponzi vagy Bernard Madoff) túl a jog keretein belül maradó, de az erkölcs határait átlépő hitelek, kölcsönök is nagy károkat tudnak okozni. Goetzmann könyvéből azt is megtudhatjuk, hogy a pénzügyekkel kapcsolatos tisztességtelen praktikák, csalások mindig is jelen voltak az emberiség történelmében. Shin azonban egyetért Goetzmann gondolatmenetével, mely szerint a pénzügy egy technológia, amely eredendően sem nem rossz, sem nem jó, amelyet az emberek jó és rossz célokra egyaránt tudnak alkalmazni. Azonban Shin felhívja a figyelmet, hogy a pénzügyek semleges mivoltának kinyilvánításán túl többet is tehetünk. Hasznosnak bizonyulhat feltenni a kérdést, hogy mely pénzügyi 
megoldások vezetnek jó célokhoz, hatékonyságnöveléshez, és fejlödéshez, illetve mely pénzügyi megoldások azok, amelyek csak a csalásokra, átverésekre, járadékvadász magatartásra szolgálnak ösztönzőként. Shin véleménye szerint Goetzmann könyve egy jó kiindulópont arra, hogy rendszerszinten azonosítani tudjuk a jó és rossz pénzügyi megoldásokat (a jó és rossz kifejezéseket Shin nem morális, hanem hatékonysági értelemben használja), valamint arra is, hogy emlékeztessen minket, hogy bár napjainkban a legfejlettebb, legösszetettebb pénzügyi rendszerrel rendelkező gazdaságban élünk, azért nem árt néhány történelemleckét vennünk.

\section{Összegzés}

Goetzmann elképesztő interdiszciplináris munkája egy rendkívül gazdag pénzügyi történelmet mutat be, amelynek jelentőségét Shin csak hangsúlyozni tudja. Shin esszéje a gazdag történelmi anyagból a szerző címben megfogalmazott hipotézisét viszi tovább, történetesen azt, hogy a pénzügyek fejlettsége mennyiben járul hozzá a gazdasági fejlődéshez. Rávilágít arra, hogy egy olyan prosperáló gazdaság, amelyet a 21. századi fejlett világban megvalósult, elképzelhetetlen lenne egy összetett pénzügyi rendszer nélkül. Ezzel együtt a pénzügyek jelenléte messze nem az egyedüli összetevője egy fejlett gazdaságnak, azonban mindenképpen az egyik lényeges eleme. A pénzügy egy technológia. Eredendően nem jó, és a történelem során az emberiség kreativitásának bizonyítékaként számtalan visszaélést, tisztességtelen pénzügyi alkalmazást, csalást is láthattunk. Shin hangsúlyozza, hogy a történelmi ismeretek sokat segíthetnek egyes pénzügyi tevékenységek szabályozása során is, és Goetzmann könyve tökéletesen alkalmas pénzügyekkel kapcsolatos igen gazdag és érdekes történelmünk megismerésére.

Bajkán Domonkos ${ }^{2}$

\section{Felhasznált irodalom:}

Buera, Francisco J., Joseph P. Kaboski, and Yongseok Shin (2011): Finance and Development: A Tale of Two Sectors. American Economic Review 101 (5): 1964-2002.

Diamond, Jared (1997): Guns, Germs, and Steel: The Fates of Human Societies. New York: W. W. Norton and Company

King, Robert G., and Ross Levine (1993): Finance and Growth: Schumpeter Might Be Right. Quarterly Journal of Economics 108 (3): 717-37.

Mokyr, Joel (2002): The Gifts of Athena: Historical Origins of the Knowledge Economy. Princeton and Oxford: Princeton University Press.

Mokyr, Joel (2016): A Culture of Growth: The Origins of the Modern Economy. Princeton and Oxford: Princeton University Press.

Rajan, Raghuram G., and Luigi Zingales (1998): Financial Dependence and Growth. American Economic Review 88 (3): $559-86$.

\footnotetext{
${ }^{2}$ egyetemi hallgató, Budapesti Corvinus Egyetem
} 